\title{
The importance of an integrated approach to provenance studies: A case study from the Paleocene of the Faroe-Shetland Basin, NE Atlantic
}

\author{
Andrew Morton \\ HM Research Associates, 2 Clive Road, Balsall Common, West Midlands CV7 7DW, UK, and CASP, University of Cambridge, \\ 181a Huntingdon Road, Cambridge CB3 ODH, UK \\ David Ellis \\ Statoil (UK) Ltd, 1 Kingdom Street, London W2 6BD, UK \\ Mark Fanning \\ Research School of Earth Sciences, Australian National University, Canberra ACT 0200, Australia \\ David Jolley \\ Department of Geology and Petroleum Geology, University of Aberdeen, Kings College, Aberdeen AB24 3UE, UK
}

Andrew Whitham

CASP, University of Cambridge, 181 a Huntingdon Road, Cambridge CB3 ODH, UK

\begin{abstract}
Four different sand types (termed FSP1, FSP2, FSP3, and FSP4) have been recognized in the Paleocene succession of the Faroe-Shetland Basin, NE Atlantic, on the basis of conventional heavy mineral analysis, major element geochemistry of garnet, trace element geochemistry of rutile, $\mathrm{U}-\mathrm{Pb}$ dating of detrital zircon, and palynofloral analysis. Sand types FSP1, FSP2, and FSP4 were all sourced from the eastern margin of the basin, whereas FSP3 was supplied from the west. No single technique discriminates all four sand types. Conventional heavy mineral analysis discriminates FSP3 from the other three sand types but does not discriminate FSP1, FSP2, and FSP4. Garnet geochemistry distinguishes FSP1, FSP2 and FSP4, but FSP3 garnet populations overlap those of FSP1 and FSP2. Rutile geochemistry distinguishes FSP2 from FSP1 and FSP4 but cannot be easily applied to FSP3 owing to the scarcity of rutile in this sand type. Zircon age spectra in FSP1, FSP2, and FSP4 are similar to one another, but FSP4 can be recognized on the basis of a higher proportion of Archean zircons. Some of the individual techniques have certain limitations: e.g., one of the key conventional heavy mineral parameters is the presence of clinopyroxene, but this is not always reliable owing to the instability of this mineral during burial diagenesis. Likewise, garnet
\end{abstract}

Morton, A., Ellis, D., Fanning, M., Jolley, D., and Whitham, A., 2012, The importance of an integrated approach to provenance studies: A case study from the Paleocene of the Faroe-Shetland Basin, NE Atlantic, in Rasbury, E.T., Hemming, S.R., and Riggs, N.R., eds., Mineralogical and Geochemical Approaches to Provenance: Geological Society of America Special Paper 487, p. 1-12, doi:10.1130/2012.2487(01). For permission to copy, contact editing@ geosociety.org. @ 2012 The Geological Society of America. All rights reserved. 
geochemistry cannot be applied to the most deeply buried sandstones in the FaroeShetland Basin owing to complete garnet dissolution. Furthermore, care is required when interpreting garnet data from sandstones that have undergone partial garnet dissolution, as there may have been modification of the range of garnet compositions as a result of the greater instability of Ca-rich garnets compared with Ca-poor types. Finally, the "Greenland flora," which occurs in association with sand type FSP3, has been found in some wells that lack FSP3 sandstones. This discrepancy is attributed to the difference in hydrodynamic behavior of palynomorphs compared with sand particles. This chapter illustrates the importance of adopting an integrated approach, as significant detail would have been lost if only one technique had been applied, and integration of a number of different techniques overcomes limitations associated with individual approaches. An integrated approach also builds a more comprehensive picture of source area characteristics.

\section{INTRODUCTION}

A wide variety of analytical methods is now available for the determination of sandstone provenance. Excluding field-based observational data such as paleocurrent measurements, methods available range from basic (such as petrography and heavy mineral analysis) to highly sophisticated (such as single-grain isotope chemistry), with a plethora of alternative approaches (such as whole-rock elemental and isotope geochemistry, single-grain major and trace element geochemistry) also being widely used. Each of these techniques has its own advantages and disadvantages, and each has a particular application that is dependent on the context of the individual case study. However, the most complete understanding of provenance comes from the application of several different complementary methods, because an integrated approach maximizes the amount of provenance information and helps to overcome any shortcomings with individual techniques. Examples of the successful integration of diverse provenance techniques include the work of Hemming et al. (1998), who applied ${ }^{40} \mathrm{Ar} /{ }^{39} \mathrm{Ar}$ analysis of amphibole, $\mathrm{Pb}$ isotopic analysis of feldspar, and $\mathrm{Nd}-\mathrm{Sr}-\mathrm{Pb}$ isotopic analysis of the fine sediment fraction to determine the provenance of ice-rafted detritus in the NE Atlantic; Khudoley et al. (2001), who used facies variations, petrography, whole-rock geochemistry, and single-grain $\mathrm{U}-\mathrm{Pb}$ zircon age dating to investigate provenance patterns in Neoproterozoic sandstones of Siberia; Garzanti et al. (2004), who used petrography, determination of the metamorphic grade of lithic particles, conventional heavy mineral analysis, and amphibole color measurements to differentiate detritus from different structural levels within the Alpine collision orogen; and Hallsworth and Chisholm (2008), who evaluated the provenance of Late Carboniferous sandstones in the Pennine Basin (UK) using conventional heavy mineral analysis, garnet geochemistry, and paleocurrent studies.

A wide variety of techniques has been used to determine the provenance of Paleocene sandstones in the Faroe-Shetland Basin, NE Atlantic, including conventional heavy mineral analysis, major element geochemistry of garnet, trace element geochemistry of rutile, $\mathrm{U}-\mathrm{Pb}$ dating of detrital zircon, and palynofloral analysis (Jolley et al., 2005; Jolley and Morton, 2007; Morton et al., 2012). This paper reviews the application of these various techniques, drawing attention to the advantages and drawbacks associated with each individual type of analysis, the aim being to demonstrate the importance of adopting an integrated approach.

\section{GEOLOGICAL SETTING}

The Faroe-Shetland Basin lies on the NW seaboard of the British Isles between the Faroe and Shetland Islands (Fig. 1). The basin, which formed as a result of multiphase Permian-Triassic, Cretaceous, and Paleocene extension followed by compression during the later part of the Tertiary (Boldreel and Andersen, 1993; Dean et al., 1999), has a dominant NE-SW tectonic grain inherited from the early Paleozoic Caledonian orogeny (Duindam and van Hoorn, 1987), and is further compartmentalized by NW-SE-trending transfer elements that dissect the Caledonian grain.

During the Paleocene, prior to final separation of Greenland from NW Europe in the early Eocene, the Faroe-Shetland area constituted a relatively narrow, restricted marine basin (Smallwood and White, 2002), with potential for sediment derived from landmasses both to the west (Greenland) and the east (OrkneyShetland Platform) to reach the basin center (Smallwood, 2005). Lamers and Carmichael (1999) suggested that most of the Paleocene clastic sediment in the UK sector of the Faroe-Shetland Basin was sourced from the east, the British Isles having been a long-lasting emergent provenance area. However, Jones et al. (2002) considered that the volume of material denuded from the eastern margin is insufficient to account for the volume of Paleocene sediment in the Faroe-Shetland Basin. According to Smallwood (2008), sediment volume balancing requires that $\sim 30 \%$ of the Paleocene sediment in the basin had a westerly provenance, the most likely candidates being East Greenland and the prebasaltic succession in the vicinity of the Faroe Isles (Fig. 1). 


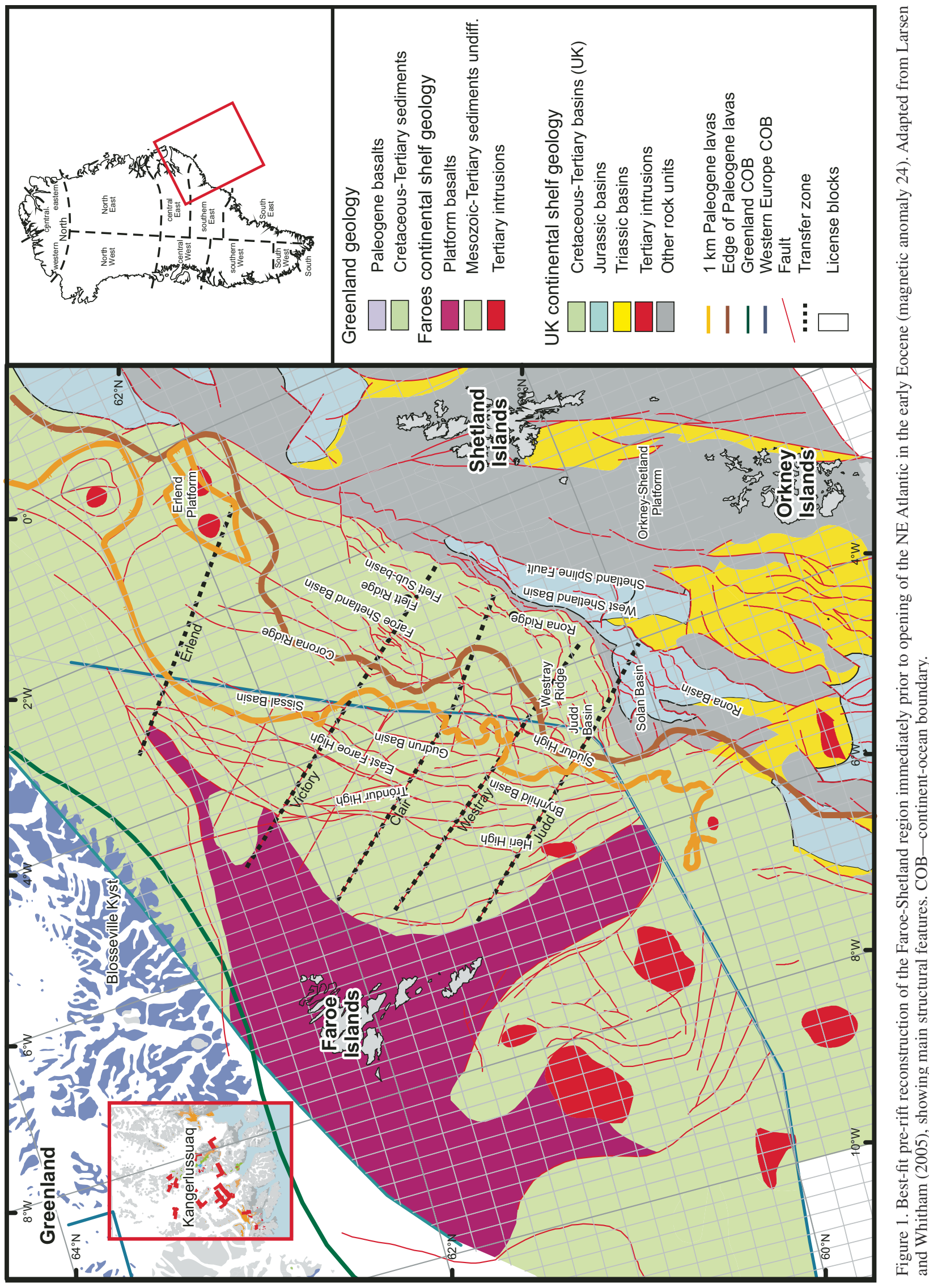


The stratigraphic interval discussed in this paper (Fig. 2) comprises the Sullom, Vaila, and Lamba Formations (sequences T10-T38 as defined by Ebdon et al., 1995). The sandstones in these formations are predominantly of mass-flow submarine fan origin (Ebdon et al., 1995; Lamers and Carmichael, 1999) and were deposited in water depths $>500 \mathrm{~m}$ (Smallwood and Gill, 2002).

Four distinct sand types (termed FSP1, FSP2, FSP3, and FSP4) have been defined in the Paleocene of the Faroe-Shetland Basin on the basis of conventional heavy mineral analysis, garnet and rutile geochemistry, $\mathrm{U}-\mathrm{Pb}$ dating of detrital zircon, and palynofloral analysis (Jolley and Morton, 2007; Morton et al., 2012). These sand types have been defined on the basis of data acquired from $>300$ samples from 17 hydrocarbon exploration wells (14 in the UK sector and 3 in the Faroes sector). The distribution of sand types FSP1-4 is shown in Figure 3. Three of the sand types (FSP1, FSP2, and FSP4) are interpreted as having been derived from the Orkney-Shetland Platform on the basis of their distribution within the basin and on evidence from seismic reflection data (Jolley and Morton, 2007; Morton et al., 2012). By contrast, sand type FSP3 is interpreted as having been derived from the west, although it is not clear if the source lay on the East Greenland landmass or whether intrabasinal structural highs were involved (Morton et al., 2012).

\section{CONVENTIONAL HEAVY MINERAL DATA}

Heavy mineral assemblages are controlled not only by provenance but also by processes that operate during the sedimentary cycle, the most important being diagenesis during deep burial, hydrodynamic processes during transport and deposition, and weathering (Morton, 1985a; Mange and Maurer, 1992; Morton and Hallsworth, 1999; Mange and Wright, 2007; Garzanti et al., 2008). The effects of the processes operative during the sedimentary cycle can be minimized by determining the relative abundance of minerals that are hydrodynamically equivalent and are stable within the context of the study (Morton and Hallsworth, 1994).

There are major variations in garnet:zircon, rutile:zircon, apatite:tourmaline (GZi, RuZi, and ATi as defined by Morton and Hallsworth, 1994) in the Paleocene of the Faroe-Shetland Basin (Jolley and Morton, 2007; Morton et al., 2012). Variations in GZi, however, are related primarily to burial depth (Fig. 4), implying that garnet has undergone partial or complete dissolution through the action of high-temperature pore waters. Evidence for garnet dissolution is also provided by the presence of surface corrosion textures on garnet similar to those illustrated by Turner and Morton (2007). Hence, GZi values cannot be used to reliably characterize or discriminate provenance, especially in the deeper parts of the basin.

Variations in RuZi and ATi (Fig. 5) enable the discrimination of sand type FSP3 from the other three sand types, with FSP1, FSP2, and FSP4 having higher RuZi values than FSP3. However, there is a small amount of overlap between RuZi values

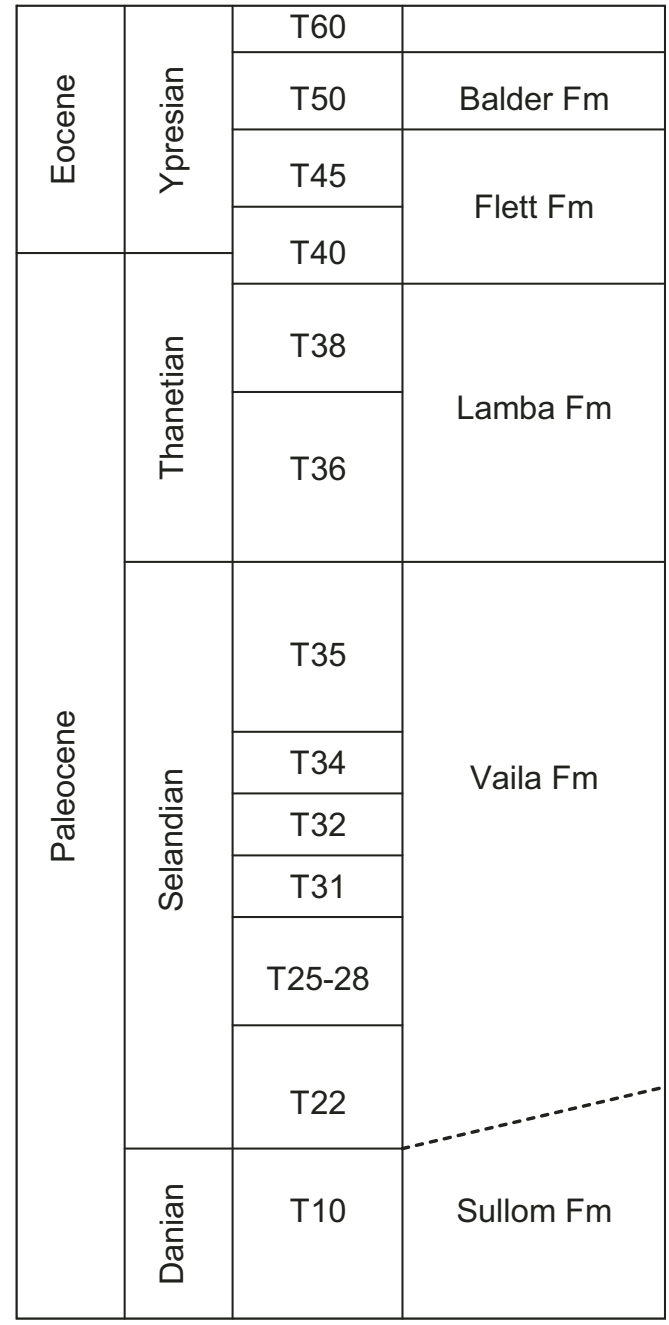

Figure 2. Paleocene-early Eocene stratigraphic framework of the Faroe-Shetland Basin. Adapted from Ebdon et al. (1995), Knox et al. (1997), Mudge and Bujak (2001), Sørensen (2003), and Jolley et al. (2005).

in FSP3 and FSP4, and hence these two sand types cannot be unequivocally distinguished on this parameter alone. Sand types FSP1, FSP2, and, to a lesser extent, FSP4, have wide ranges in ATi, whereas FSP3 has uniformly high ATi. Within the FSP1 sand type there is evidence for a difference between the two most northern wells (208/17-2 and 208/19-1) and the remainder, the northern wells tending to have higher RuZi and lower ATi (Fig. 5). However, as there is a degree of overlap, these differences are considered insufficient to formally allow definition of two different sand types at this time.

The distribution of clinopyroxene is another important variable within the conventional heavy mineral data set. Clinopyroxene is indicative of supply from mafic igneous lithologies, and as the early Tertiary basalt lava fields are in the western parts of the Faroe-Shetland Basin (Fig. 1), its presence suggests that 
Importance of an integrated approach to provenance studies
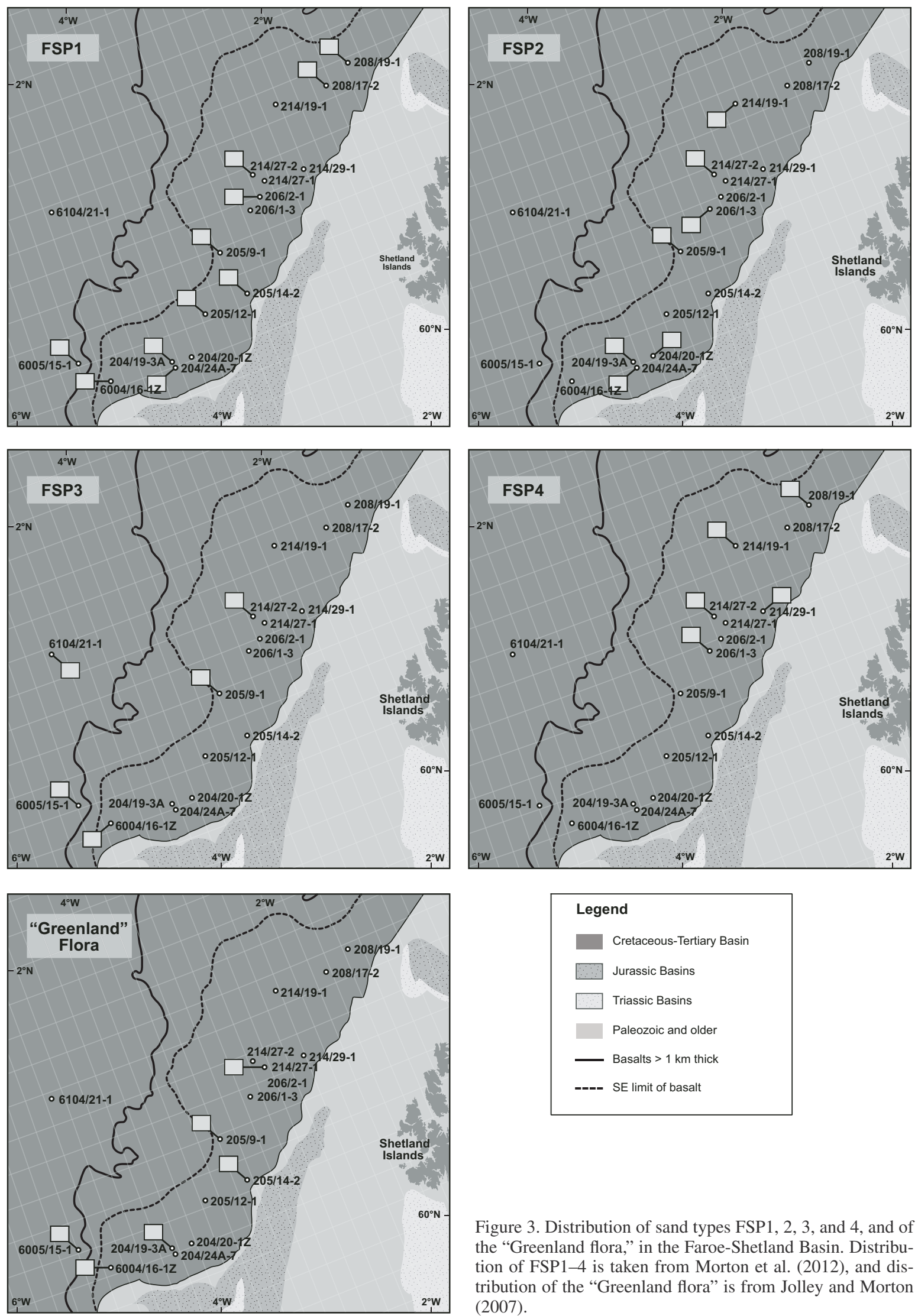

Figure 3. Distribution of sand types FSP1, 2, 3, and 4, and of the "Greenland flora," in the Faroe-Shetland Basin. Distribution of FSP1-4 is taken from Morton et al. (2012), and distribution of the "Greenland flora" is from Jolley and Morton (2007). 


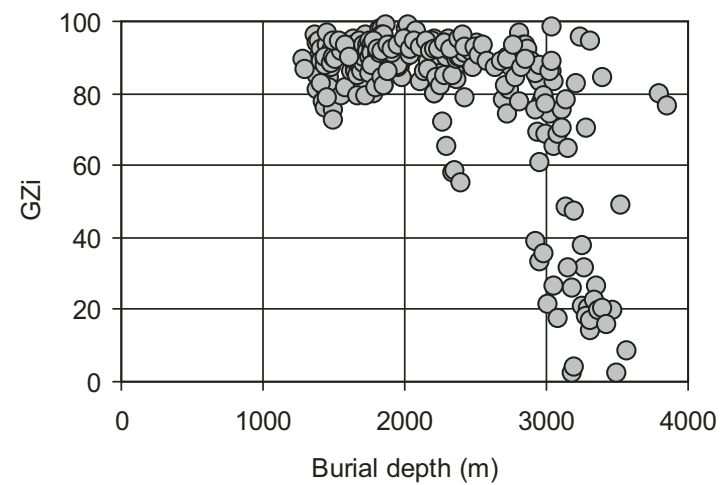

Figure 4. Relationship between garnet:zircon index (GZi) and present-day burial depth in Paleocene samples from the Faroe-Shetland Basin. the sediment in which it occurs was derived from the west. As shown in Figure 6, clinopyroxene occurs only in sandstones with low RuZi (sand type FSP3). Hence, sand type FSP3 is interpreted as having a western provenance. However, the absence of clinopyroxene does not preclude derivation from the west, because clinopyroxene is one of the most unstable heavy minerals during burial diagenesis (Morton and Hallsworth, 2007).

In summary, conventional heavy mineral data distinguish sand type FSP3 from the other types on the basis of RuZi and the presence of clinopyroxene, but the other three sand types cannot be discriminated from each other. Furthermore, there is a limited amount of overlap in RuZi values between FSP3 and FSP4, and the absence of clinopyroxene does not rule out assigning a

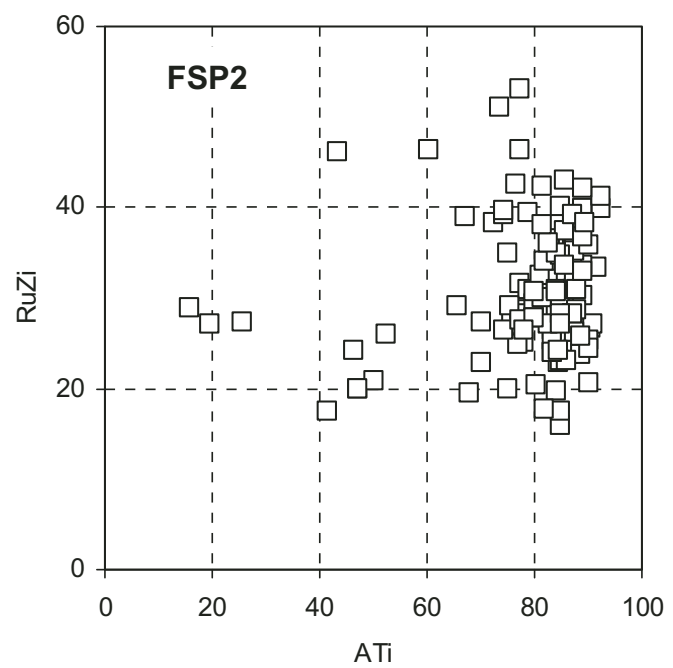

$\triangle$ Southern area $\Delta$ Northern area

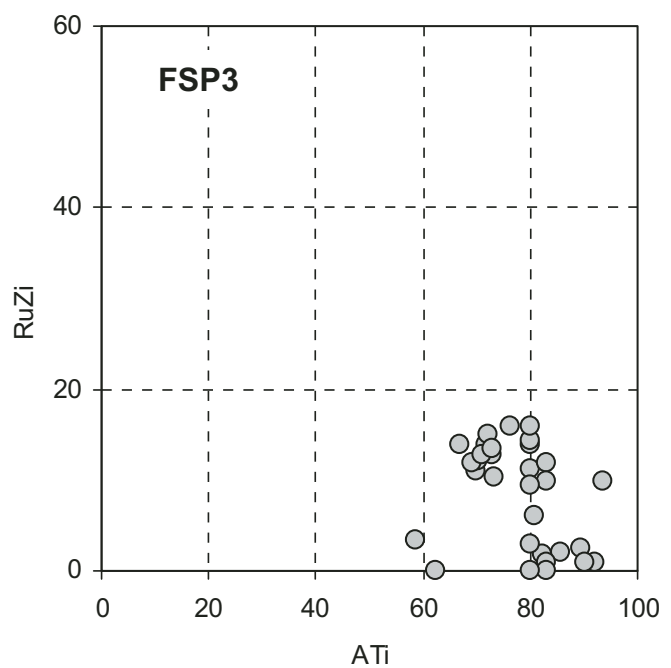

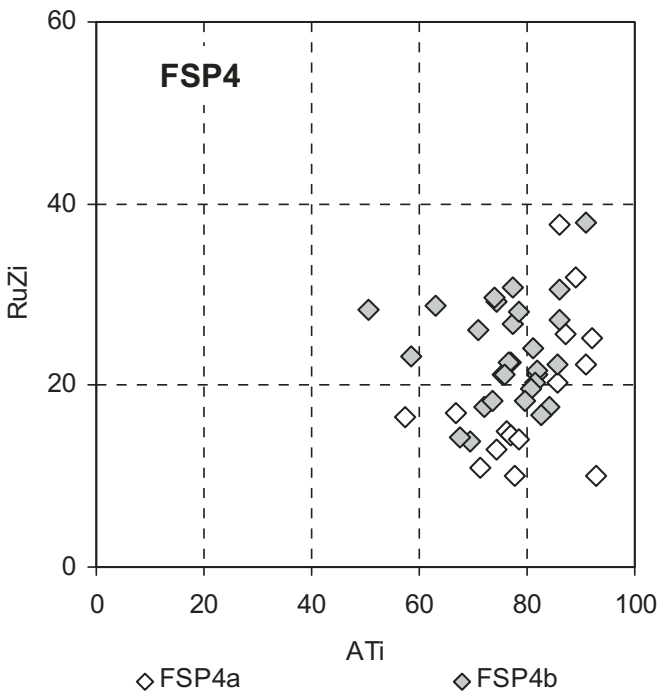

Figure 5. Plots of rutile:zircon index (RuZi) and apatite:tourmaline index (ATi) for sand types FSP1, FSP2, FSP3, and FSP4. 
sample to FSP3 owing to the instability of this mineral during burial diagenesis.

\section{GARNET GEOCHEMISTRY}

Major element garnet geochemistry has been widely used as a provenance tool since electron microprobe analysis revealed the existence of wide variations in the compositions of detrital garnet populations in Middle Jurassic sandstones of the northern North Sea (Morton, 1985b). Since then, garnet geochemistry has been

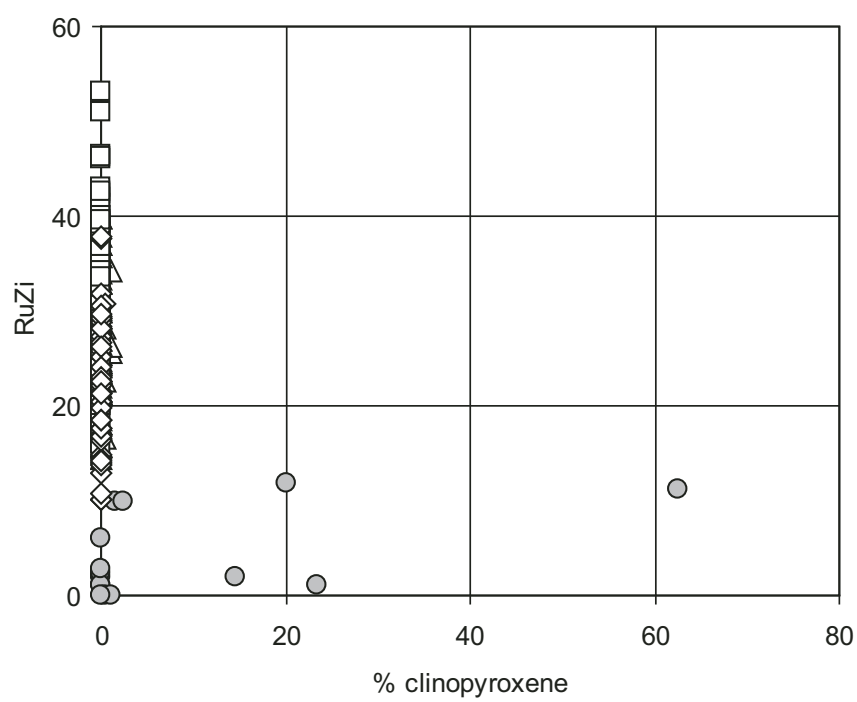

$$
\begin{array}{ll}
\triangle \text { Sand type FSP1 } & \square \text { Sand type FSP2 } \\
\text { O Sand type FSP3 } & \diamond \text { Sand type FSP4 }
\end{array}
$$

Figure 6. Relationship between rutile:zircon index (RuZi) and clinopyroxene abundance. used to constrain the provenance of sediments ranging in age from Paleozoic to Holocene in sedimentary basins worldwide. A review of the application of garnet geochemistry in sedimentary provenance analysis can be found in Mange and Morton (2007).

Garnet assemblages in Paleocene-Eocene sandstones from the Faroe-Shetland Basin (Fig. 7) show large differences in major element composition (Jolley and Morton, 2007; Morton et al., 2012). These variations are manifested by the relative proportions of garnet types $\mathrm{Ai}$, Aii, and $\mathrm{B}+\mathrm{C}$, as defined by Morton et al. (2004), Mange and Morton (2007), and Jolley and Morton (2007). Sand type FSP1 is dominated by garnet types B and C $(\mathrm{B}+\mathrm{C}>\sim 70 \%)$. This contrasts with sand type FSP2 in which Type Ai garnet forms between $30 \%$ and $60 \%$ of the populations in most cases (Fig. 8). A small number of FSP2 samples have higher Type Ai contents, but these are all from deeply buried sandstones that have undergone partial garnet dissolution. Because Ca-rich garnets are less stable than Ca-poor varieties during burial diagenesis (Morton, 1987; Morton and Hallsworth, 2007), the relative abundance of stable garnets (such as Type A) tends to increase as burial diagenesis proceeds. Sand type FSP4 is characterized by common Type Aii garnet ( $>30 \%)$, and has been subdivided into two subtypes, FSP4a and FSP4b on the basis of their Ai garnet content. FSP4a has low proportions of Type Ai garnet, whereas FSP4b has higher Type Ai contents (Fig. 8).

Hence, garnet geochemistry effectively discriminates FSP1, FSP2, and FSP4. However, FSP3 sandstones have garnet assemblages that overlap the FSP1 and FSP2 fields (Fig. 8), and therefore sand type FSP3 cannot be distinguished from FSP1 and FSP2 on the basis of garnet geochemistry. The application of the technique is also limited by the instability of garnet in the deepest parts of the basin.

\section{RUTILE GEOCHEMISTRY}

Rutile trace element geochemistry is being increasingly used as a provenance tool since the recognition that the two main rutile

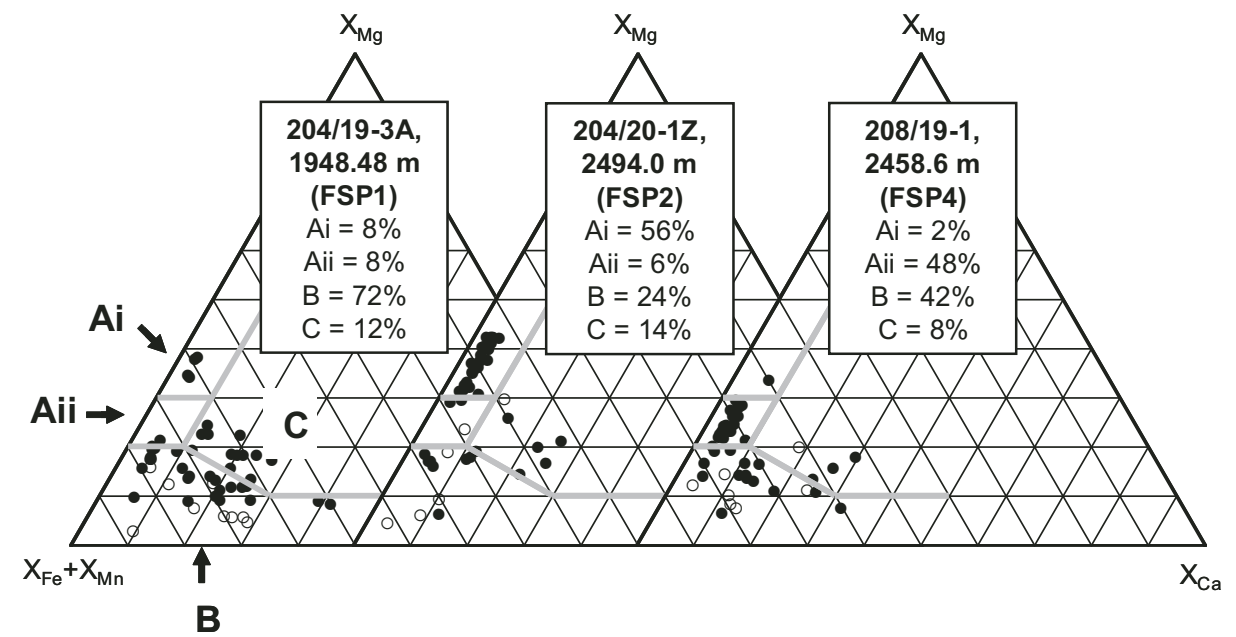

Figure 7. Representative garnet ternary diagrams for sand types FSP1, FSP2, and FSP4. Garnet types Ai, Aii, B, and $\mathrm{C}$ are as defined by Morton et al. (2004), Mange and Morton (2007), and Jolley and Morton (2007). 


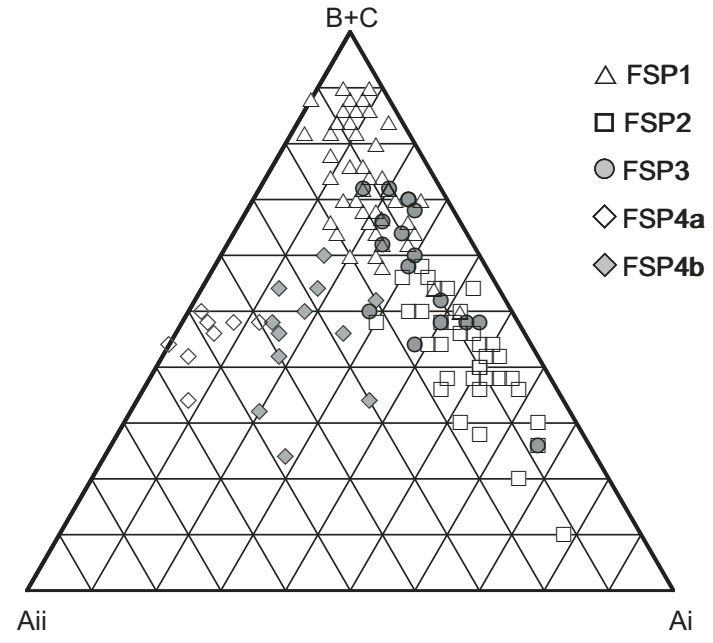

Figure 8. Relative abundance of garnet types Ai, Aii, and $\mathrm{B}+\mathrm{C}$, showing the differentiation of sand types FSP1, FSP2, and FSP4, and the overlap shown by FSP3.

sources (metapelitic and metamafic rocks) can be distinguished using $\mathrm{Cr}$ and $\mathrm{Nb}$ contents, and that $\mathrm{Zr}$ contents can be used as a direct measure of metamorphic formation temperature (Zack et al., 2004; Meinhold et al., 2008).

There are variations in rutile provenance in the Paleocene of the Faroe-Shetland Basin, expressed in terms of both source lithotype (metamafic or metapelitic) and metamorphic grade (Fig. 9). Sand type FSP2 is distinguished from FSP1 and FSP4 by high abundances of granulite-facies metapelitic rutile (Fig. 10). The rutiles in FSP1 and FSP4 formed under similar metamorphic conditions, although the limited amount of available data suggests that FSP1 has slightly higher proportions of granulite-facies rutile compared with FSP4. There appear to be geographical variations in the relative abundance of metamafic and metapelitic rutile within sand type FSP1, the two most northern wells (208/17-2 and 208/19-1) containing more metamafic rutile (Fig. 10). The rutile data therefore support the evidence from conventional heavy mineral data (Fig. 5), which also suggest that the sandstones in these wells had a different provenance. Rutile geochemical data cannot be used to discriminate sand type FSP3 owing to the scarcity of rutile.

There is a strong correlation between granulite-facies metapelitic rutile and Type Ai garnet, both being abundant in sand type FSP2 and less common in sand types FSP1 and FSP4 (Fig. 11). The main source of Type A garnet is believed to be high-grade metasediments and charnockites (Sabeen et al., 2002; Mange and Morton, 2007), and a link between abundance of Type A garnet and granulite-facies metapelitic rutile was recently established in a study of Jurassic-Paleocene sandstones in the Norwegian Sea (Morton and Chenery, 2009). However, the rutiles in sand type FSP4, which is characterized by Type Aii garnet, are predominantly metamafic and formed under amphibolite-facies (principally lower amphibolite-facies) conditions. It therefore appears that Type Aii garnets do not necessarily form under high-grade (granulite-facies) conditions, and may be associated with a metamafic rutile provenance.

\section{ZIRCON AGE DATA}

The use of single grain U-Pb dating of detrital zircon has become prevalent in sediment provenance studies in recent years, owing to the fact that zircon is virtually ubiquitous in sediments by virtue of its high level of stability during weathering and burial diagenesis. Differences in Paleocene sand provenance in the Faroe-Shetland Basin have been explored using detrital zircon age data. Seven samples covering the four sand types were included in the zircon analytical program (Fig. 12). In broad terms, the seven samples have similar age spectra, in that all contain a well-defined Archean group peaking in the 2700-2800 Ma range, together with a range of Paleoproterozoic-Mesoproterozoic zircons $(\sim 1000$ $1900 \mathrm{Ma})$ that generally lack a well-defined age structure. In addition, early Paleozoic zircons corresponding to the Caledonian orogeny are present in minor amounts $(<18 \%)$, and some samples contain rare zircons with Permian-Triassic ages.

The main variation within the zircon data set relates to the abundance of Archaean grains. In most cases, Archean zircons form $\sim 30 \%-40 \%$ of the populations, but the two samples with FSP3 mineralogy (UK well 205/9-1, 3712.40 m; Faroes well $6104 / 21-1,3777 \mathrm{~m}$ ) contain a significantly higher proportion $(63 \%-65 \%)$. The zircon age data therefore confirm the heavy mineral evidence for a difference in provenance between FSP3 and FSP1, 2 and 4, but do not appear to be useful in distinguishing FSP1, FSP2, and FSP4.

\section{PALYNOLOGY}

Although the principal aim of palynological analysis is to provide constraints on stratigraphy, the technique may also provide important information on sediment provenance. This is because the terrestrial palynomorphs (pollen and spores) that are preserved in marine basins are derived from vegetation growing within catchment areas at the basin margins. In marine basins with salinity stratification, or where there is major input from large fluvial systems, the pollen and spore load may be transported for considerable distances offshore. Such conditions occurred in the NE Atlantic during the Paleocene and early Eocene, resulting in the offshore transfer of large volumes of terrigenous plant debris (Naylor et al., 1999).

Regional differences in ecological conditions around the margins of the Faroe-Shetland Basin have enabled the differentiation of westerly- and easterly-derived palynofloras (Jolley et al., 2005; Jolley and Morton, 2007). Palynofloras derived from the westerly source (termed the "Greenland flora") are characterized by the common occurrence of Cupuliferoipollenites and Cupuliferoidaepollenites (Fagaceae) in association with Momipites species (Juglandaceae). 


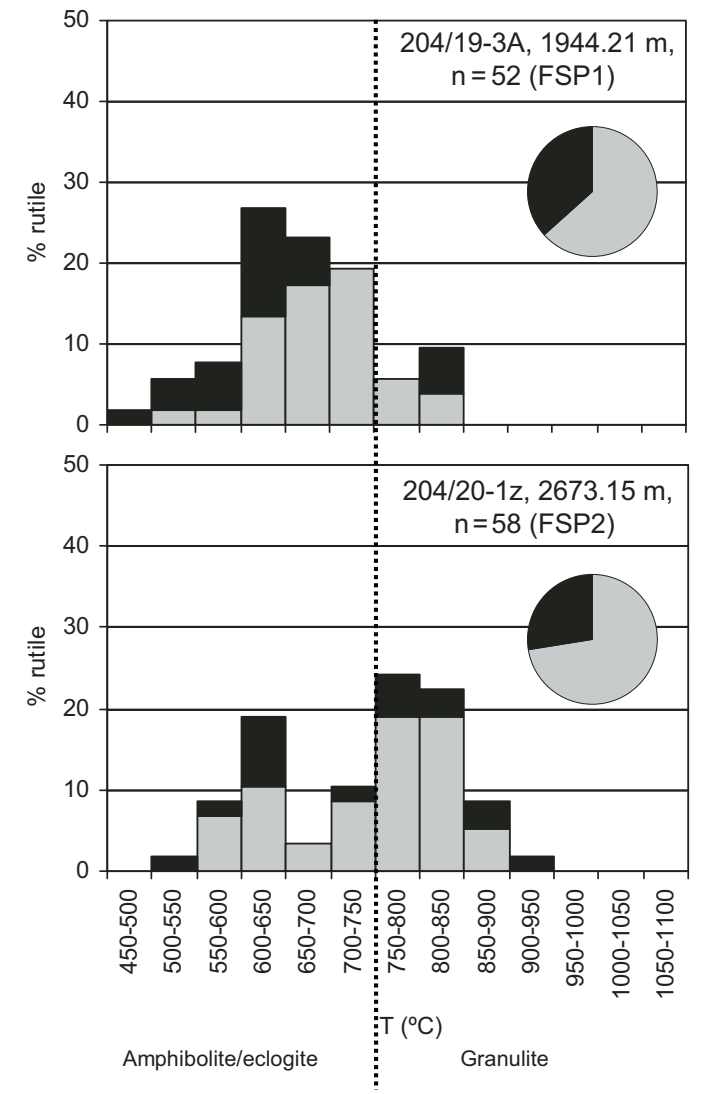

Metapelitic

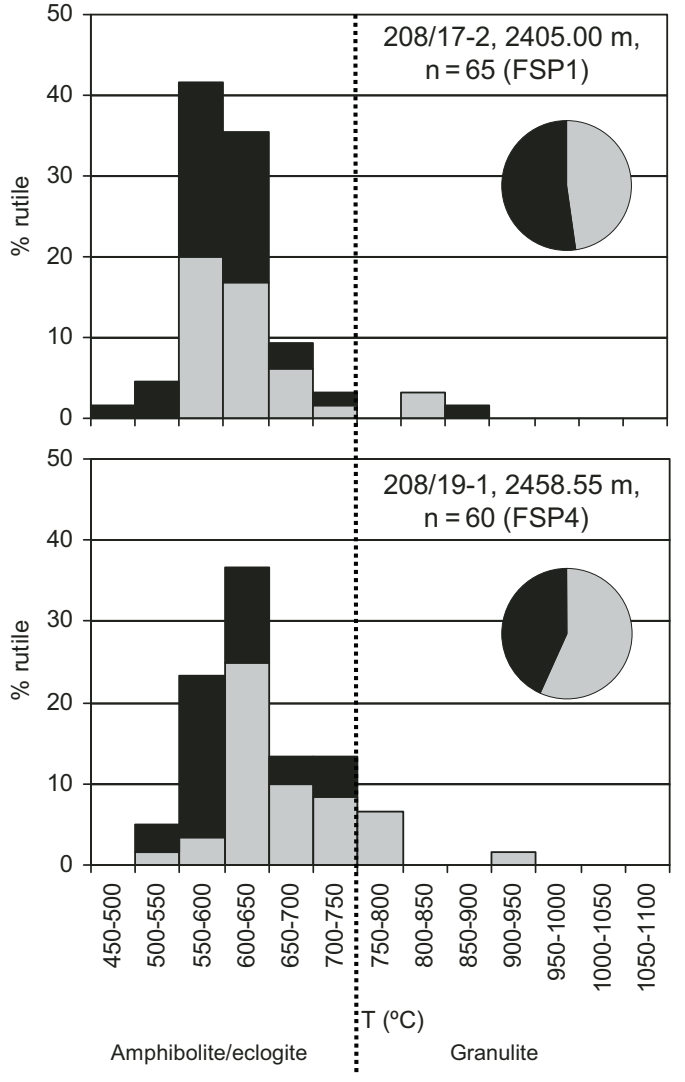

Metamafic

Figure 9. Rutile geochemistry for sand types FSP1, FSP2, and FSP4. Note the contrast in rutile provenance between the two FSP1 samples, one from the southern part of the area (UK well 204/19-3A) and one from the north (UK well 208/17-2).

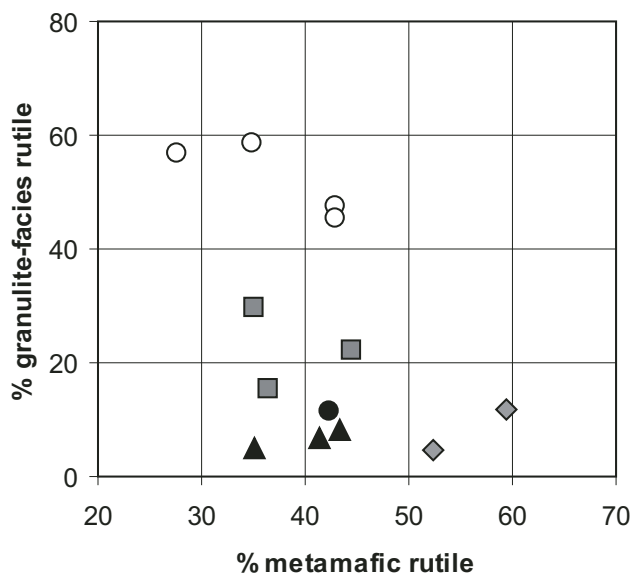

口FSP1 $\diamond$ FSP1 (north) OFSP2 $\Delta$ FSP4a $\bullet$ FSP4b

Figure 10. Variations in abundance of metamafic rutile and granulite-facies rutile in sand types FSP1, FSP2, and FSP4.

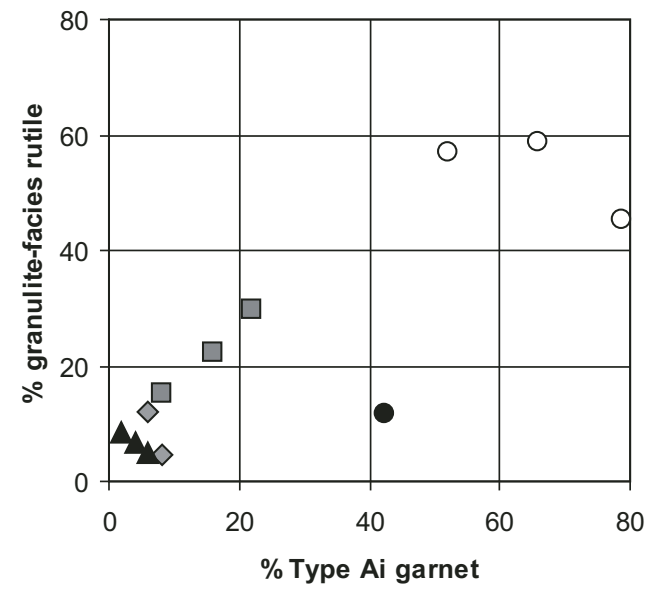

$\square$ FSP1 $\diamond$ FSP1 (north) OFSP2 $\Delta$ FSP4a • FSP4b

Figure 11. Relationship between abundance of granulitefacies rutile and Type Ai garnet in the Paleocene of the Faroe-Shetland Basin. 


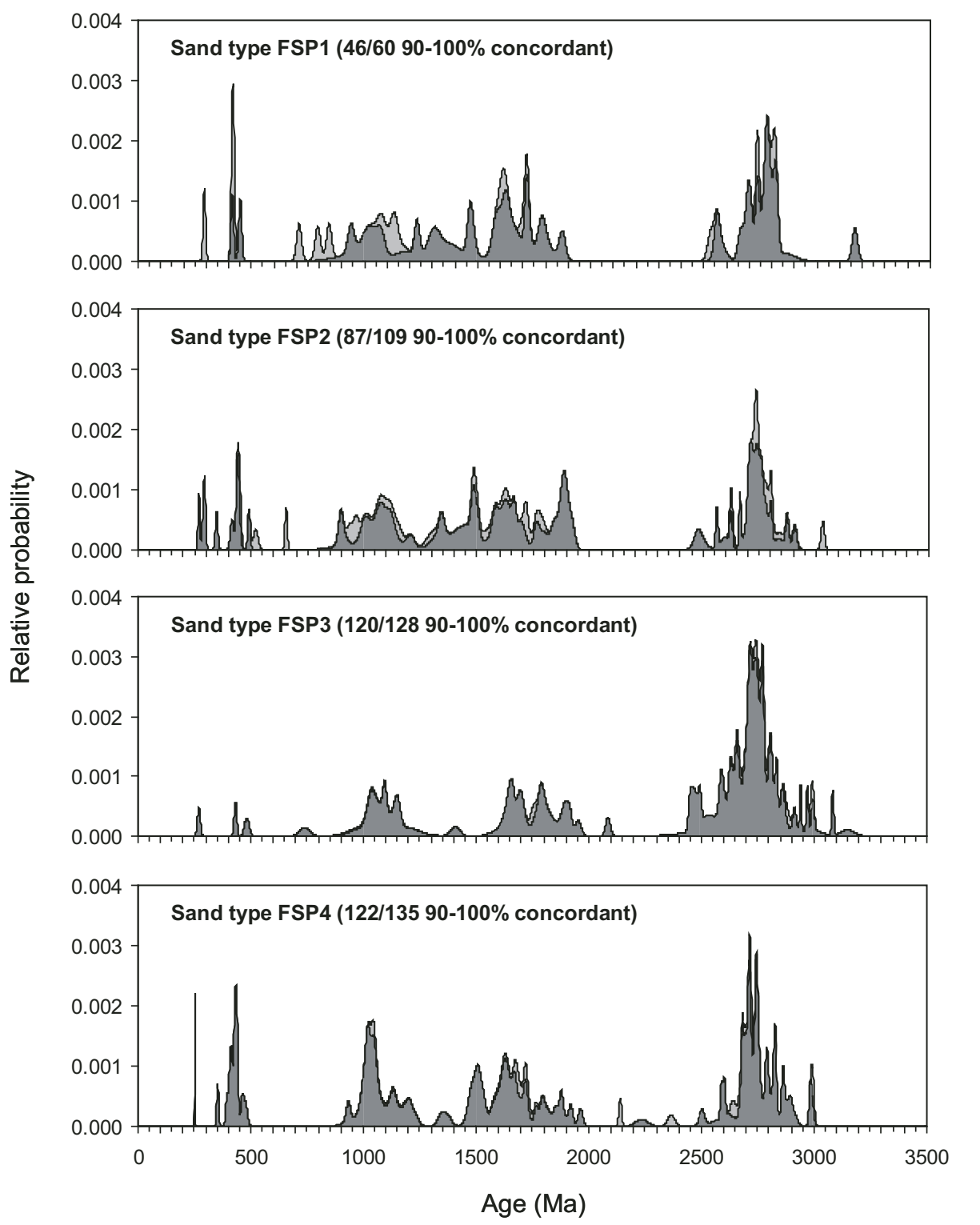

Figure 12. Zircon age spectra in FSP1, FSP2, FSP3, and FSP4 sandstones displayed as relative probability plots generated using AgeDisplay (Sircombe, 2004).

The "Greenland flora" has been found in a relatively large number of wells in the Faroe-Shetland Basin (Fig. 3) and has a wider distribution within the basin compared with sand type FSP3, which is the only coarse clastic component with a known western origin. Importantly, all the intervals that have FSP3 characteristics also contain the "Greenland flora" (Jolley and Morton, 2007; Morton et al., 2012). The only exception is well 214/27-2, which has not been studied palynologically: however, the adjacent well 214/27-1 does contain the "Greenland flora" at the equivalent stratigraphic level (Fig. 3). Hence, the palynofloral data provide further evidence that sand type FSP3 was derived from the west.

The presence of the "Greenland flora" in wells that lack sand type FSP3 is attributed to the difference in hydrodynamic behav- ior of palynomorphs compared with sand particles. Terrestrially derived palynomorphs fall into the 5-60 $\mu \mathrm{m}$ size range and therefore have hydrodynamic properties comparable with silt-size sedimentary particles. As a result, they are likely to remain in suspension for longer periods than sand particles derived from the same region. In consequence, they can be transported farther offshore than sand particles, accounting for their wide distribution in the Paleocene of the Faroe-Shetland Basin.

\section{DISCUSSION AND CONCLUSIONS}

Four distinct sand types, three (FSP1, FSP2, and FSP4) derived from the Orkney-Shetland Platform margin, and one (FSP3) supplied from the west, have been identified in the 
Paleocene succession of the Faroe-Shetland Basin. These sand types have been recognized using a number of criteria, including conventional heavy mineral parameters (notably rutile:zircon indices and the abundance of clinopyroxene), mineral chemistry (major-element garnet and trace element rutile compositions), detrital zircon age spectra, and terrestrially derived palynoflora.

The integrated approach followed in this study has been crucial in the recognition of these four sand types and the determination of their provenance, because they cannot be distinguished on the basis of one single parameter.

- The rutile:zircon index (RuZi) distinguishes sand type FSP3 from the other types but cannot discriminate FSP1, FSP2, and FSP4. Furthermore, there is a limited amount of overlap in RuZi values between FSP3 and FSP4.

- Clinopyroxene is present only in sand type FSP3, but not every FSP3 sandstone sample contains clinopyroxene owing to the instability of this mineral during burial diagenesis.

- Garnet geochemistry is the main parameter that has been used to distinguish FSP1, FSP2, and FSP4. However, FSP3 garnet populations overlap those of FSP1 and FSP2. Furthermore, this technique cannot be used in the deeper parts of the basin owing to the extensive garnet dissolution at burial depths exceeding $4 \mathrm{~km}$.

- Rutile geochemistry clearly differentiates FSP2 from FSP1 and FSP4 and may help distinguish FSP1 from FSP4, although insufficient data are presently available to test this possibility. Rutile geochemistry is difficult to apply to FSP3 owing to its low rutile content.

- Zircon geochronology has relatively poor discriminatory value in this region. It is helpful in distinguishing FSP3 from FSP1, 2 , and 4 on the basis of the abundance of the Archean component, but it does not enable differentiation of any of the other three sand types.

- As with the conventional heavy mineral, mineral chemical, and zircon age data, terrestrially derived palynofloral assemblages identify input to the Faroe-Shetland Basin from both west and east. However, the distribution of the westerly derived "Greenland flora" is wider than the distribution of the westerly derived sand type FSP3. The apparent decoupling of pollen and sand provenance is interpreted as the result of their different hydrodynamic behavior. Smallwood (2008) estimated that $30 \%$ of the Paleocene sediments in the Faroe-Shetland Basin were sourced from the west on the basis of sediment volume balancing calculations, but only $\sim 10 \%$ of the samples in the data set have FSP3 characteristics. This apparent contradiction is partly explained by the strong sampling bias owing to the distribution of wells, which are mostly close to the eastern margin of the basin, but it may also be partly attributable to the fact that heavy mineral data concentrate only on the coarse clastic component of the sediment fill. It is evident from studies of terrestrially derived palynoflora that westerly derived material is more widely distributed in the finer grained components of the succession.
This study demonstrates that understanding the complexity of sand provenance in sedimentary basins requires an integrated approach, and that significant detail is likely to be lost if only one provenance tool is employed. In this instance, zircon age dating proved to be relatively poor at distinguishing different sediment transport systems, but in other cases (such as the Cretaceous of the Norwegian Sea) the technique proved more useful than garnet geochemistry (Morton et al., 2005). In recent years, many provenance studies have concentrated solely on detrital zircon age dating. This approach is probably the only technique that can be successfully applied to the provenance analysis of metasedimentary successions where other heavy mineral components have been destroyed, such as the Dalradian Supergroup of Scotland (Cawood et al., 2003). However, as the current study shows, ignoring the information stored in other components of sandstones may result in an incomplete understanding of provenance patterns in sedimentary basins. Furthermore, an integrated approach maximizes the amount of provenance information and is crucial in building up a detailed picture of the lithological, mineralogical, and geochronological constitution of sediment source regions.

\section{ACKNOWLEDGMENTS}

Support from Sindri enabled heavy mineral studies of the Paleocene succession in the Faroe-Shetland Basin, and Anardarko, ConocoPhillips, British Petroleum, and Statoil supported detrital zircon age dating studies in the area. We are grateful to Guido Meinhold and John Smallwood for their constructive reviews.

\section{REFERENCES CITED}

Boldreel, L.O., and Andersen, M.S., 1993, Late Paleocene to Miocene compression in the Faeroe-Rockall area, in Parker, J.R., ed., Petroleum Geology of Northwest Europe: Proceedings of the 4th Conference: Geological Society [London], p. 1025-1034.

Cawood, P.A., Nemchin, A.A., Smith, M., and Loewy, S., 2003, Source of the Dalradian Supergroup constrained by U-Pb dating of detrital zircon and implications for the East Laurentian margin: Journal of the Geological Society [London], v. 160, p. 231-246, doi:10.1144/0016-764902-039.

Dean, K., McLachlan, K., and Chambers, A., 1999, Rifting and the development of the Faeroe-Shetland Basin, in Fleet A.J., and Boldy, S.A.R., eds., Petroleum Geology of Northwest Europe: Proceedings of the 5th Conference: Geological Society [London], p. 533-544.

Duindam, P., and van Hoorn, B., 1987, Structural evolution of the west Shetland continental Margin, in Brooks, J., and Glennie, K.W., eds., Petroleum Geology of Northwest Europe: London, Graham and Trotman, p. 765-773.

Ebdon, C.C., Granger, P.J., Johnson, H.D., and Evans, A.M., 1995, Early Tertiary evolution and sequence stratigraphy of the Faeroe-Shetland Basin: Implications for hydrocarbon prospectivity, in Scrutton, R.A., Stoker, M.S., Shimmield, G.B., and Tudhope, A.W., eds., The Tectonics, Sedimentation and Palaeoceanography of the North Atlantic Region: Geological Society [London] Special Publication 90, p. 51-69.

Garzanti, E., Vezzoli, G., Lombardo, B., Andò, S., Mauri, E., Monguzzi, S., and Russo, M., 2004, Collision-orogen provenance (western Alps): Detrital signatures and unroofing trends: The Journal of Geology, v. 112, p. 145164, doi:10.1086/381655

Garzanti, E., Andò, S., and Vezzoli, G., 2008, Settling equivalence of detrital minerals and grain-size dependence of sediment composition: Earth 
and Planetary Science Letters, v. 273, p. 138-151, doi:10.1016/j.epsl .2008.06.020

Hallsworth, C.R., and Chisholm, J.I., 2008, Provenance of late Carboniferous sandstones in the Pennine Basin (UK) from combined heavy mineral, garnet geochemistry and palaeocurrent studies: Sedimentary Geology, v. 203, p. 196-212, doi:10.1016/j.sedgeo.2007.11.002.

Hemming, S.R., Broecker, W.S., Sharp, W.D., Bond, G.C., Gwiazda, R.H., McManus, J.F., Klas, M., and Hajdas, I., 1998, Provenance of Heinrich layers in core V28-82, northeastern Atlantic: ${ }^{40} \mathrm{Ar}{ }^{39} \mathrm{Ar}$ ages of ice-rafted hornblende, $\mathrm{Pb}$ isotopes in feldspar grains, and $\mathrm{Nd}-\mathrm{Sr}-\mathrm{Pb}$ isotopes in the fine sediment fraction: Earth and Planetary Science Letters, v. 164, p. 317-333, doi:10.1016/S0012-821X(98)00224-6.

Jolley, D.W., and Morton, A.C., 2007, Understanding basin sedimentary provenance using allied phytogeographic and heavy mineral analytical techniques: Evidence for sediment transfer pathways in the Paleocene of the north-east Atlantic: Journal of the Geological Society [London], v. 164 p. 553-563, doi:10.1144/0016-76492005-187.

Jolley, D.W., Morton, A.C., and Prince, I., 2005, Climate and volcanogenic impact on phytogeography and sediment dispersal patterns in the NE Atlantic, in Doré, A.G., and Vining, B., eds., Petroleum Geology: NorthWest Europe and Global Perspectives: Proceedings of the 6th Petroleum Geology Conference: Geological Society [London], p. 969-975.

Jones, S.M., White, N., Clarke, B.J., Rowley, E., and Gallagher, K., 2002, Present and past influence of the Iceland Plume on sedimentation, in Doré, A.G., Cartwright, J.A., Stoker, M.S., Turner, J.P., and White, N., eds., Exhumation of the North Atlantic Margin: Timing, Mechanisms and Implications for Petroleum Exploration: Geological Society [London] Special Publication 196, p. 13-25.

Khudoley, A.K., Rainbird, R.H., Stern, R.A., Kropachev, A.P., Heaman, L.M., Zanin, A.M., Podkovyrov, V.N., Belova, V.N., and Sukhorukov, V.I., 2001, Sedimentary evolution of the Riphean-Vendian basin of southeastern Siberia: Precambrian Research, v. 111, p. 129-163, doi:10.1016/S0301 $-9268(01) 00159-0$.

Knox, R.W.O'B., Holloway, S., Kirby, G.A., and Baily, H.E., 1997, Stratigraphic nomenclature of the UK North West Margin. 2. Early Paleogene Lithostratigraphy and Sequence Stratigraphy: Nottingham, British Geological Survey.

Lamers, E., and Carmichael, S.M.M., 1999, The Paleocene deepwater sandstone play west of Shetland, in Fleet, A.J., and Boldy, S.A.R., eds., Petroleum Geology of Northwest Europe: Proceedings of the 5th Conference: Geological Society [London], p. 645-659.

Larsen, M., and Whitham, A.G., 2005, Evidence for a major sediment input point into the Faroe-Shetland Basin from the Kangerlussuaq region of southern East Greenland, in Doré, A., and Vining, B., eds., Petroleum Geology: North-West Europe and Global Perspective: Proceedings of the 6th Petroleum Geology Conference: Geological Society [London], p. 913-922

Mange, M.A., and Maurer, H.F.W., 1992, Heavy Minerals in Colour: London, Chapman and Hall, $147 \mathrm{p}$.

Mange, M.A., and Morton, A.C., 2007, Geochemistry of heavy minerals, in Mange, M., and Wright, D.T., eds., Heavy Minerals in Use: Developments in Sedimentology, v. 58: Amsterdam. Elsevier, p. 345-391.

Mange, M., and Wright, D.T., eds., 2007, Heavy Minerals in Use: Developments in Sedimentology, v. 58: Amsterdam, Elsevier, 1283 p.

Meinhold, G., Anders, B., Kostopoulos, D., and Reischmann, T., 2008, Rutile chemistry and thermometry as provenance indicator: An example from Chios Island, Greece: Sedimentary Geology, v. 203, p. 98-111, doi:10.1016/j.sedgeo.2007.11.004

Morton, A.C., 1985a, Heavy minerals in provenance studies, in Zuffa, G.G., ed., Provenance of Arenites: Dordrecht, Reidel, p. 249-277.

Morton, A.C., 1985b, A new approach to provenance studies: Electron microprobe analysis of detrital garnets from Middle Jurassic sandstones of the northern North Sea: Sedimentology, v. 32, p. 553-566, doi:10.1111/j.1365-3091.1985.tb00470.x.

Morton, A.C., 1987, Influences of provenance and diagenesis on detrital garnet suites in the Forties sandstone, Paleocene, central North Sea: Journal of Sedimentary Petrology, v. 57, p. 1027-1032.

Morton, A.C., and Chenery, S., 2009, Detrital rutile geochemistry and geothermometry as guides to provenance of Jurassic-Paleocene sandstones of the Norwegian Sea: Journal of Sedimentary Research, v. 79, p. 540-553, doi:10.2110/jsr.2009.054
Morton, A.C., and Hallsworth, C.R., 1994, Identifying provenance-specific features of detrital heavy mineral assemblages in sandstones: Sedimentary Geology, v. 90, p. 241-256, doi:10.1016/0037-0738(94)90041-8.

Morton, A.C., and Hallsworth, C.R., 1999, Processes controlling the composition of heavy mineral assemblages in sandstones: Sedimentary Geology, v. 124, p. 3-29, doi:10.1016/S0037-0738(98)00118-3.

Morton, A.C., and Hallsworth, C.R., 2007, Stability of detrital heavy minerals during burial diagenesis, in Mange, M., and Wright, D.T., eds., Heavy Minerals in Use: Developments in Sedimentology, v. 58: Amsterdam, Elsevier, p. 215-245.

Morton, A.C., Hallsworth, C.R., and Chalton, B., 2004, Garnet compositions in Scottish and Norwegian basement terrains: A framework for interpretation of North Sea sandstone provenance: Marine and Petroleum Geology, v. 21, p. 393-410, doi:10.1016/j.marpetgeo.2004.01.001.

Morton, A.C., Whitham, A.G., and Fanning, C.M., 2005, Provenance of Late Cretaceous-Paleocene submarine fan sandstones in the Norwegian Sea: Integration of heavy mineral, mineral chemical and zircon age data: Sedimentary Geology, v. 182, p. 3-28, doi:10.1016/j.sedgeo.2005.08.007.

Morton, A., Ellis, D., Fanning, M., Jolley, D., and Whitham, A., 2012, Heavy mineral constraints on Paleocene sand transport routes in the FaroeShetland Basin, in Varming, T., ed., Proceedings of the 3rd Faroe Islands Exploration Conference (in press).

Mudge, D.C., and Bujak, J.P., 2001, Biostratigraphic evidence for evolving palaeoenvironments in the Lower Paleogene of the Faeroe-Shetland Basin: Marine and Petroleum Geology, v. 18, p. 577-590, doi:10.1016/ S0264-8172(00)00074-X

Naylor, P.H., Bell, B.R., Jolley, D.W., Durnall, P., and Fredstead, R., 1999, Palaeogene magmatism in the Faeroe-Shetland Basin: Influences on uplift history and sedimentation, in Fleet, A.J., and Boldy, S.A.R., eds., Petroleum Geology of Northwest Europe: Proceedings of the 5th Conference: Geological Society [London], p. 545-558.

Sabeen, H.M., Ramanujam, N., and Morton, A.C., 2002, The provenance of garnet: Constraints provided by studies of coastal sediments from Southern India: Sedimentary Geology, v. 152, p. 279-287, doi:10.1016/S0037 $-0738(02) 00083-0$.

Sircombe, K.N., 2004, AgeDisplay: An EXCEL workbook to evaluate and display univariate geochronological data using binned frequency histograms and probability density distributions: Computers \& Geosciences, v. 30, p. 21-31, doi:10.1016/j.cageo.2003.09.006.

Smallwood, J.R., 2005, Quantity, distribution and provenance of Paleocene sediments in the Faroe-Shetland area, in Ziska, H., Varming, T., and Bloch, D., eds., Faroe Islands Exploration Conference 2004 Proceedings: Tórshavn, Annales Societatis Scientiarum Færoensis, p. 82-95.

Smallwood, J.R., 2008, Uplift, compression and the Cenozoic Faroe-Shetland sediment budget, in Johnson, H., Doré, A.G., Gatliff, R.W., Holdsworth, R., Lundin, E.R., and Ritchie, J.D., eds., The Nature and Origin of Compression in Passive Margins: Geological Society [London] Special Publication 306, p. 137-152.

Smallwood, J.R., and Gill, C.E. 2002, The rise and fall of the Faroe-Shetland Basin: Evidence from seismic mapping of the Balder Formation: Journal of the Geological Society [London], v. 159, p. 627-630 doi: 10.1144/0016-764902-064.

Smallwood, J.R., and White, R.S., 2002, Ridge-plume interaction in the North Atlantic and its influence on continental breakup and seafloor spreading, in Jolley, D.W., and Bell., B.R., eds., The North Atlantic Igneous Province: Stratigraphy, Tectonic, Volcanic and Magmatic Processes: Geological Society [London] Special Publication 197, p. 15-37.

Sørensen, A.B., 2003, Cenozoic basin development and stratigraphy of the Faroes area: Petroleum Geoscience, v. 9, p. 189-207, doi:10.1144/1354 $-079302-508$.

Turner, G., and Morton, A.C., 2007, The effects of burial diagenesis on detrita heavy mineral grain surface textures, in Mange, M., and Wright, D.T. eds., Heavy Minerals in Use: Developments in Sedimentology, v. 58: Amsterdam, Elsevier, p. 393-412.

Zack, T., von Eynatten, H., and Kronz, A., 2004, Rutile geochemistry and its potential use in quantitative provenance studies: Sedimentary Geology, v. 171, p. 37-58, doi:10.1016/j.sedgeo.2004.05.009.

Manuscript Accepted by the Society 29 November 2011 